\title{
The application of Monod equation to denitrification kinetics description in the moving bed biofilm reactor (MBBR)
}

\author{
L. Kopec ${ }^{1}$ [ $\cdot$ A. Kopec ${ }^{2} \cdot$ J. Drewnowski³
}

Received: 11 July 2017 / Revised: 5 March 2018 / Accepted: 11 May 2018 / Published online: 8 June 2018

(c) The Author(s) 2018

\begin{abstract}
In this paper, the kinetic constants $V_{\max }$ and $K_{\mathrm{COD}}$ occurring in the Monod equation, which describe the denitrification process in the moving bed, are determined. For this purpose, a laboratory moving bed biofilm reactor (MBBR) was used. The filling of the reactor consisted of EvU Perl carriers. The experiment was carried out with an excess of nitrate, and denitrification rate was dependent on the concentration of external organic carbon, which constituted the Brennta Plus preparation. Determination of constants was made by Hofstee-Eadie method, whereby there was obtained: $V_{\max }=0.78 \mathrm{~g} \mathrm{NO}_{3}{ }^{-}-\mathrm{N} / \mathrm{g}$ D.M./ day and $K_{\mathrm{COD}}=16.97 \mathrm{~g} \mathrm{O}_{2} / \mathrm{m}^{3}$. The new Monod equation was verified using MBBR constructed on an industrial scale in wastewater treatment plant in Gronowo Górne (Poland). After joining the MBBR to the technological system and after a period of biomass adaptation, total nitrogen removal efficiency increased from 53.5 to $86.0 \%$. The results of the research have been discussed with several similar researches.
\end{abstract}

Keywords MBBR $\cdot$ Moving bed biofilm reactor $\cdot$ Denitrification $\cdot$ Nitrogen removal $\cdot$ Wastewater treatment $\cdot$ Monod equation $\cdot$ Kinetics of denitrification

\section{Introduction}

In Poland, in small biological treatment plants designed for less than 2000 people (using usually activated sludge or biofilters) the removal of ammonia nitrogen, due to its toxic effect, was the one of the most important issues so far. The matter of removing oxygen forms of nitrogen-nitrite and nitrate (denitrification process), is usually secondary importance and often remains unresolved. It contributes to the contamination of surface water in Poland, which is exposed to eutrophication process (Obarska-Pempkowiak

Editorial responsibility: Binbin Huang.

\section{Kopec}

lk@ekofinn.pl

Ekofinn-Pol Ltd, ul. Lesna 12, 80-297 Banino, Poland

2 Department of Mechanical Engineering, Koszalin University of Technology, ul. Raclawicka 15-17, 75-620 Koszalin, Poland

3 Faculty of Civil and Environmental Engineering, Gdansk University of Technology, ul. Narutowicza 11/12, 80-233 Gdańsk, Poland et al. 2015; Jucherski and Nastawny 2012; Sytek-Szmeichel et al. 2016).

To protect the surface water-efficient devices for the complete removal of contaminants from wastewater, resistant to variable rate and the leaching of biomass should be sought. This is especially important for non-urbanized areas, where process control is hindered (Gajewska et al. 2011).

Ammonium removal (more accurately nitrite/nitrate removal) is really a big challenge faced by both largescale and small-scale WWTPs, mainly due to the insufficient carbon sources in wastewater. Moreover, there are significant differences between centralized wastewaters (i.e., large scale) and decentralized wastewaters (i.e., small scale) according to Chen et al. 2016. Fullscale evaluation of aerobic/extended-idle AEI zone was affected by seasonal variation, and the efficiencies of contaminant removal were stable and excellent (total nitrogen $>86 \%$, others $>92 \%$ ) in the integrated system. This study offers an attractive option for biological nutrient removal (BNR) from carbohydrate-rich wastewaters and also provides a prototype for wastewater treatment in remote areas. For small treatment plants relationship between the rate of nitrates removal and available substrate can be described by Monod equation. There is no 
need to apply any advanced equation, but simple one with two constants: $V_{\max }$-describing the maximum rate of denitrification and $K_{\mathrm{COD}}$-characterizing the substrate concentration at which half the maximum rate is reached. The aim of this study was to determine the kinetic constants $V_{\max }$ and $K_{\mathrm{COD}}$ occurring in the Monod equation. The constants describe denitrification process in a moving bed. The laboratory moving bed biofilm reactor (MBBR) was used to determination. The filling of the reactor consisted of EvU Perl carriers. Designated equation was verified using a MBBR constructed on an industrial scale in WWTP in Gronowo Górne (Poland). The study which was conducted during a summer period (August-September 2015) has also determined the efficiency of denitrification before and after joining the MBBR device to the technological system in order to enhance biochemical processes efficiency of wastewater.

\section{Materials and methods}

A test stand simulating the operation of a small MBBR was constructed in the laboratory. It was assumed that the operation of the laboratory reactor is similar to MBBR under denitrification process in the real conditions. The construction of these two reactors (in the laboratory and the pilot scale) is shown in Fig. 1a, b. During the constructing of the reactors, the description of MBBR given by Rusten et al. (2006) was used.

The laboratory MBBR (Fig. 1a) consisted of container with a capacity of $28 \mathrm{~L}$, and it was made of transparent plastic (Plexiglas). A working volume of device was $24 \mathrm{~L}$. Moving bed-Evu Perl carriers took $25 \%$ of the working volume $(6 \mathrm{~L})$. Centrally in the reactor a stirrer with two blades of $8 \mathrm{~cm}$ length was placed. Stirrer shaft was driven by a motor with speed control. Frequency of mixing was $100 \mathrm{rpm}$ (because at this value did not occur oxygenation and all moving carriers of filling were touched). More details of the construction and operation of a laboratory MBBR has been shown in studies by Kopeć et al. (2016).

The reactor was filled with wastewater coming from the WWTP in Gronowo Gorne (Poland). The wastewater imported from this facility is characterized by a high concentration of nitrates $\left(86 \mathrm{mg} \mathrm{N} / \mathrm{dm}^{3}\right)$ and low values of biodegradable COD. The ratio $\mathrm{COD} / \mathrm{N}$ was 8.6. To the reactor a variable dose of nitrates $\left(\mathrm{NaNO}_{3}\right)$ and the external organic carbon source in the form of Brennta Plus formulation were added. After addition of substrates, the biomass able to denitrification grew itself. The research was carried out at $20^{\circ} \mathrm{C}$ during a summer period (August-September 2015).

The external organic carbon source (expressed as COD) was the rate-limiting substrate for the denitrification reaction. Nitrates were always in excess, as not to affect the rate of the process. According to Metcalf \& Eddy Inc. et al. (2013), Liwarska-Bizukojć (2014) and Mąkinia (2006), nitrates could be rate-limiting substrate for the denitrification; however, the Monod constant value for nitrate $\left(K_{\mathrm{N}}\right)$ is very low in the range $0.2-0.4 \mathrm{mg} \mathrm{N} / \mathrm{dm}^{3}$ and difficult to determine, even under laboratory conditions. The low value of this constant proves that practically it does not affect the process. (a)

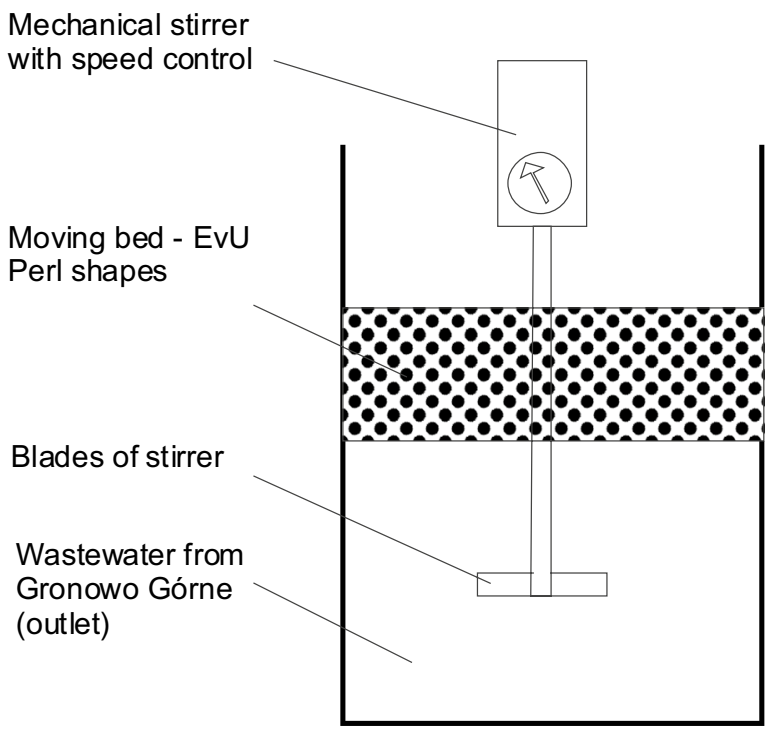

(b)

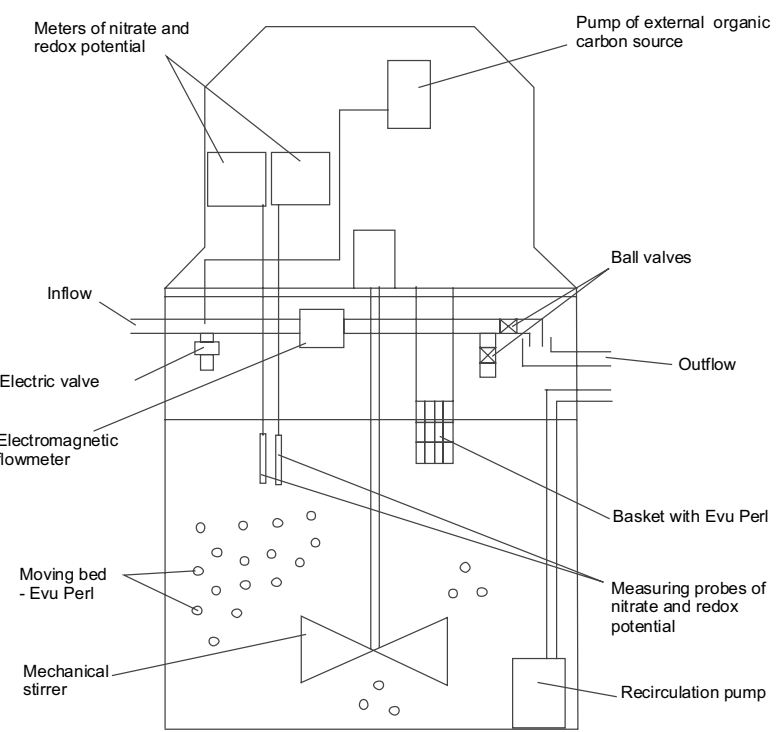

Fig. 1 Scheme of moving bed biofilm reactor: in the laboratory (a) and in the industrial scale (b) 
The measurements included readily and slowly biodegradable COD fractions. In order to obtain a division into fractions, after each series of measurements reactor was aerated for $3 \mathrm{~h}$ and COD concentration was analyzed. This value corresponds to the fraction, which was slowly degradable. From the difference of the total COD and slowly biodegradable fraction of COD concentration, readily degradable fraction was obtained.

During operation of the reactor, denitrification rate was determined by measuring the time intervals and the concentration of nitrate, readily biodegradable COD and the biomass concentration. Denitrification rate value depending on the initial concentration of the substrate established a set of points $\left[C_{\mathrm{COD}(0)}, V\right]$ by which constants in Monod equation were determined.

Denitrification rate Eq. (1) given by Henze et al. (2008) comprises a kinetic constants, in which knowledge is necessary to specifically describe the process. These are: the maximum rate of denitrification $-V_{\max }$, Monod constant for nitrates $-K_{\mathrm{N}}$ and Monod constant for organic matter expressed in $\mathrm{COD}-K_{\mathrm{COD}}$.

$V=V_{\max } \cdot \frac{C_{\mathrm{N}}}{K_{\mathrm{N}}+C_{\mathrm{N}}} \cdot \frac{C_{\mathrm{COD}}}{K_{\mathrm{COD}}+C_{\mathrm{COD}}}$

According to Mąkinia et al. (2006), Monod constant for nitrate $\left(K_{\mathrm{N}}\right)$ is very small, so it can be applied in a simplified form of Monod Eq. (2):

$V=V_{\max } \cdot \frac{C_{\mathrm{COD}}}{K_{\mathrm{COD}}+C_{\mathrm{COD}}}$

Sets of points $\left[C_{\mathrm{COD}(0)} ; V\right]$ obtained in a laboratory experiment were the basis for plotting Monod function. The procedure was performed according to the calculation instructions given by Klimiuk et al. (1995), Cema et al. (2012) and Liwarską-Bizukojć (2014). Hyperbolic function of Monod

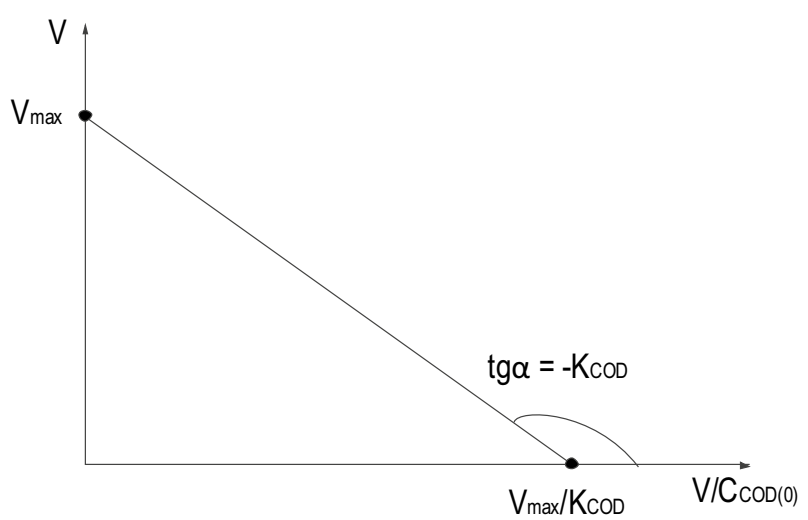

Fig. 2 Graphic presentation of the Hofstee-Eadie linearization method was converted into a linear form using Hofstee-Eadie linearization method. According to Szewczyk (2005), this method has the smallest calculation error. Graphic form of the conversion is shown in Fig. 2. The linear Eq. (3) has the coefficients a and $\mathrm{b}$, which correspond to kinetic constants $K_{\mathrm{COD}}(4)$ and $V_{\max }(5)$.

$r_{\mathrm{su}}=-K_{\mathrm{S}} \cdot \frac{r_{\mathrm{su}}}{C_{0}}+V_{\mathrm{max}}$

$a=-K_{\mathrm{S}}$

$b=V_{\max }$

In the laboratory, eight series of measurements were carried out, where the denitrification rate was limited by concentration of readily degradable organic carbon external source (Brennta Plus), nitrates were in excess and the biomass concentration mostly in suspended form was increasing from 0.11 to 0.16 g D.M./L. during 2 days.

The reactor working in the WWTP in Gronowo Górne (Fig. 1b) was a tank in the shape of a cylinder with a diameter of $2.3 \mathrm{~m}$ and a height of $2.5 \mathrm{~m}$. Its volume was $6.4 \mathrm{~m}^{3}$. The wall of the reactor was made of laminate. It consisted of two layers with a polyurethane foam between them that provided good thermal insulation. In the upper part of the reactor (over the surface of the wastewater), a platform was mounted, on which a mechanical stirrer was installed with a power of $1.1 \mathrm{~kW}$ and a speed of $50 \mathrm{rpm}$. An interior of the platform cover was a room, where a control panel and a dosing pump of external organic carbon were placed. In the reactor was present the floating moving bed-Evu Perl in total volume of $1.6 \mathrm{~m}^{3}$, which constituted $25 \%$ of the active volume. The amount of filing was adjusted taking into consideration that its too extensive percentage share caused problems with mixing. In the MBBR, the conditions necessary to achieve denitrification were maintained, such as:

(a) $\mathrm{pH}$ : 6.5-8,

(b) The availability of an external organic carbon,

(c) Temperature about $20^{\circ} \mathrm{C}$ (August-September)

(d) The presence of nitrates,

(e) Total surface of EvU Perl filling $800 \mathrm{~m}^{2} / \mathrm{m}^{3}$

By the MBBR at full scale (Fig. 1b), the Monod equation was verified. Eleven measuring series were performed in which biomass varied from 0.1 to 2.1 gD.M./L. The MBBR was conducted in anoxic conditions and continuously monitored, according to the measurement of the redox potential value, which was around $-50 \mathrm{mV}$. Wastewater in the reactor was completely mixed; therefore, the hydraulic retention time (HRT) was amounted to about $6 \mathrm{~h}$. 
The collected data (including 430 measurements) were used to calculate the Monod equation of the denitrification process in the reactor MBBR. All measurements were made according to the APHA (1992) by Standard Methods. This research used the following equipment:

1. Nitrates $\left(\mathrm{NO}_{3}\right)$ - the measurement was performed using a set of WTW ION 340i meter and the probe of nitrate NO800 (350 measurements).

2. COD-Macherey-Nagel Nanocolor cuvette tests used. The absorbance measurement was made by the portable photometer PF-11 of the same producer company ( 80 measurements),

3. The redox potential-performed a second WTW ION 340i meter and SenTix ORP probe (350 measurements).

4. The concentration of biomass-determination was carried out by gravimetric method using the Radwag MAC 50/1 moisture analyzer (150 measurements).

5. Ammonia-Macherey-Nagel Nanocolor cuvette tests used. The absorbance measurement was made by the portable photometer PF-11 of the same producer company (80 measurements).

\section{Results and discussion}

The result of the Hofstee-Eadie linearization method is shown in Fig. 3. Through the points $\left[C_{\mathrm{COD}(0)} ; V\right]$, which were obtained in the measurement, a linear function described by the equation was conducted (6):

$V=-K_{\mathrm{COD}} \cdot \frac{V}{C_{\mathrm{COD}(0)}}+V_{\max }=-16.97 \cdot \frac{V}{C_{\mathrm{COD}(0)}}+0.78$

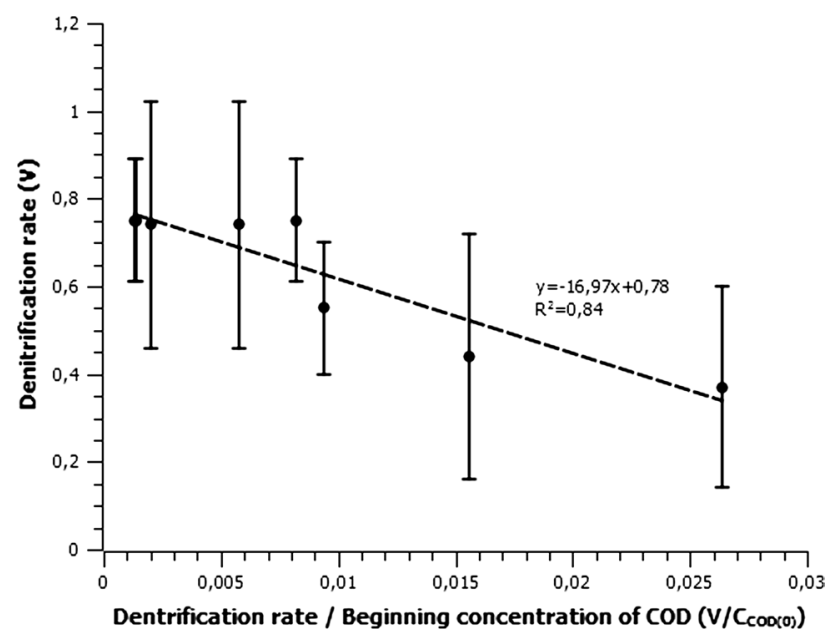

Fig. 3 Determination of $V_{\max }$ and $K_{\mathrm{COD}}$ by Hofstee-Eadie linearization method
With a high determination coefficient of 0.84 , the coefficients $a$ and $b$ corresponding to the constants: $V_{\max }$ and $K_{\mathrm{COD}}$, were determined. These values are: $a=-K_{\mathrm{COD}}=-16.97 \pm 6.97 \mathrm{~g} \quad \mathrm{O}_{2} / \mathrm{m}^{3}$, $b=V_{\max }=0.78 \pm 0.10 \mathrm{gN} / \mathrm{gD}$. M./day.

After substituting constants, a Monod equation was obtained (7) characterizing the process of denitrification in a laboratory MBBR, which is shown in Fig. 4.

$-V=0.78( \pm 0.10) \cdot \frac{C_{\mathrm{COD}}}{16.97( \pm 6.97)+C_{\mathrm{COD}}}$

$\mathrm{V}_{\max }$ constant $\left(0.78 \mathrm{~g} \mathrm{NO}_{3}{ }^{-}-\mathrm{N} / \mathrm{gD}\right.$.M./day) corresponds to the maximum rate of denitrification in a laboratory MBBR. This value is often determined by other authors by " $k$ " symbol and depends on the technology used in the realization of denitrification. Therefore, $V_{\max }$ is variable that in a wide range depends on the type of reactor, its location in the technological system, kind of external carbon source, environmental conditions (e.g., temperature) and other factors. Relative to previously used external organic carbon sources, the most similar values are obtained for ethanol Aspergen et al. (1998) $-0.80 \mathrm{gNO}_{3}{ }^{-}-\mathrm{N} / \mathrm{gD} . \mathrm{M}$./day and Pastorelli et al. (1997) $-0.71 \mathrm{gNO}_{3}{ }^{-}-\mathrm{N} / \mathrm{g}$ D.M./day. These results confirm studies of Yen-Hui (2008), who in presented calculations gained $0.82 \mathrm{~g} \mathrm{NO}_{3}{ }^{-}-\mathrm{N} / \mathrm{g}$ D.M./day. Rusten et al. (2006) achieved significantly higher rate of denitrification amounting $1.28 \mathrm{~g} \mathrm{NO}_{3}^{-}-\mathrm{N} / \mathrm{gD} . \mathrm{M}$./day for ethanol.

Based on the value of Monod constant $K_{\mathrm{COD}}$, when the results relate only to the readily biodegradable fraction of COD, it can be known for which substrate concentration of the half of the maximum rate of denitrification is achieved. This value is a measure of the susceptibility of

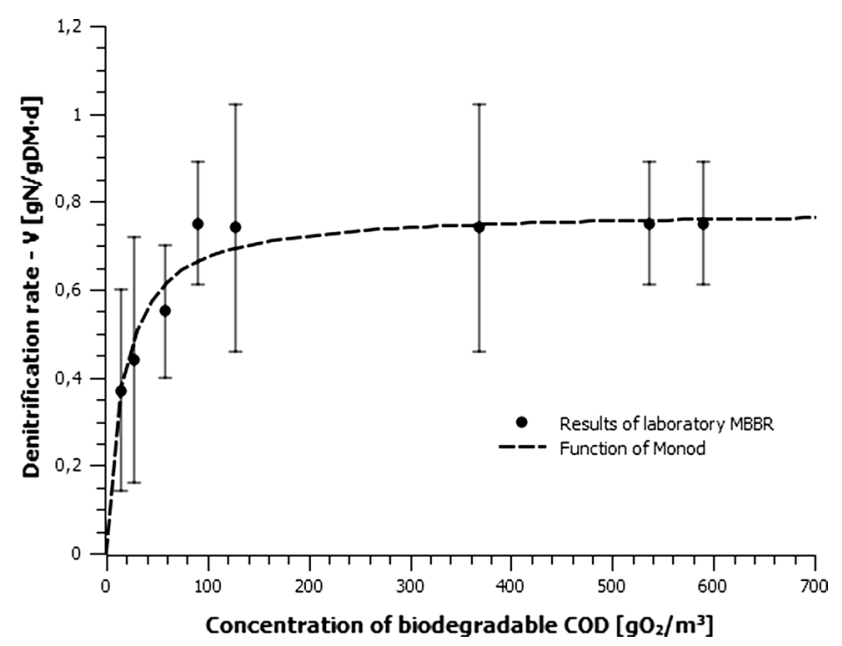

Fig. 4 Relationship between the denitrification rate and the initial concentration of external organic carbon 
the substrate for biodegradation. The resulting value of the constant $K_{\mathrm{COD}}$ is $16.97 \mathrm{~g} \mathrm{O}_{2} / \mathrm{m}^{3}$ and is comparable with the values given by other authors. Mąkinia (2006) reported that a glucose value of the constant is $17.4 \mathrm{~g}$ $\mathrm{O}_{2} / \mathrm{m}^{3}$. In research of Yen-Hui (2008), this value is similar-15.85 $\mathrm{g} \mathrm{O}_{2} / \mathrm{m}^{3}$.

The producer of external source of organic carbonBrenntag Ltd., did not specify the chemical composition of the preparation-Brennta Plus. However, based on the value of $K_{\mathrm{COD}}$, it can be assumed that readily degradable substrate compounds have properties similar to glucose. Brennta Plus preparation is susceptible for biodegradation as dissolved organic matter in the wastewater (as volatile fatty acidsVFA). By Henze et al. (2008), VFA allow to get the value of the $K_{\mathrm{COD}}$ in the range of $10-20 \mathrm{~g} \mathrm{O}_{2} / \mathrm{m}^{3}$. A similar value of the $K_{\mathrm{COD}}\left(20 \mathrm{~g} \mathrm{O}_{2} / \mathrm{m}^{3}\right)$ is also declared by Onnis-Hayden and $\mathrm{Gu}$ (2008) for another commercial source of organic carbon-MicroC preparation.

Similar research was performed by Aesoy and Odegaard (1994), who obtained a $V_{\max }$ of $0.567 \mathrm{~g} \mathrm{NO}_{3}^{-}-\mathrm{N} / \mathrm{gD} . \mathrm{M} . /$ day and a $K_{\mathrm{COD}}$ of $3 \mathrm{~g} \mathrm{O}_{2} / \mathrm{m}^{3}$. The course of the Monod function achieved by the authors is compared with the results in Fig. 5.

The maximum rate of the process in a pilot reactor was similar to the value obtained in laboratory. The initial concentration of $300 \mathrm{~g} \mathrm{O}_{2} / \mathrm{m}^{3}$ was $0.69 \mathrm{~g} \mathrm{NO}_{3}{ }^{-}-\mathrm{N} / \mathrm{gD}$.M./ day, subsequently for $500 \mathrm{~g} \mathrm{O}_{2} / \mathrm{m}^{3}$ was $0.76 \mathrm{gNO}_{3}{ }^{-} \mathrm{N} / \mathrm{g}$ D.M./day, and finally for $700 \mathrm{~g} \mathrm{O}_{2} / \mathrm{m}^{3}$ the value was $0.73 \mathrm{~g}$ $\mathrm{NO}_{3}{ }^{-}-\mathrm{N} / \mathrm{g}$ D.M./day. It means that the rate of denitrification slightly varied in a wide range of concentrations starting from $120 \mathrm{~g} \mathrm{O}_{2} / \mathrm{m}^{3}$. On average, the denitrification rate in the MBBR in Gronowo Górne was $0.73 \mathrm{~g} \mathrm{NO}_{3}{ }^{-}-\mathrm{N} / \mathrm{g}$ D.M./day.

However, the Monod constant $K_{\mathrm{COD}}$ for an external carbon source, expressed in COD, is different from the value determined in laboratory conditions. The full-size MBBR in Gronowo Górne achieved half speed of rate when the value of the biodegradable COD was about $80 \mathrm{~g} \mathrm{O}_{2} / \mathrm{m}^{3}$ (Fig. 6), but in the laboratory this value was about $17 \mathrm{~g} \mathrm{O}_{2} / \mathrm{m}^{3}$. The difference may be due to the fact that in the initial measurement series denitrifying bacteria have not completed the phase of adaptation to the
Fig. 5 Comparison of laboratory research with the results of Aesoy and Odegaard (1994)

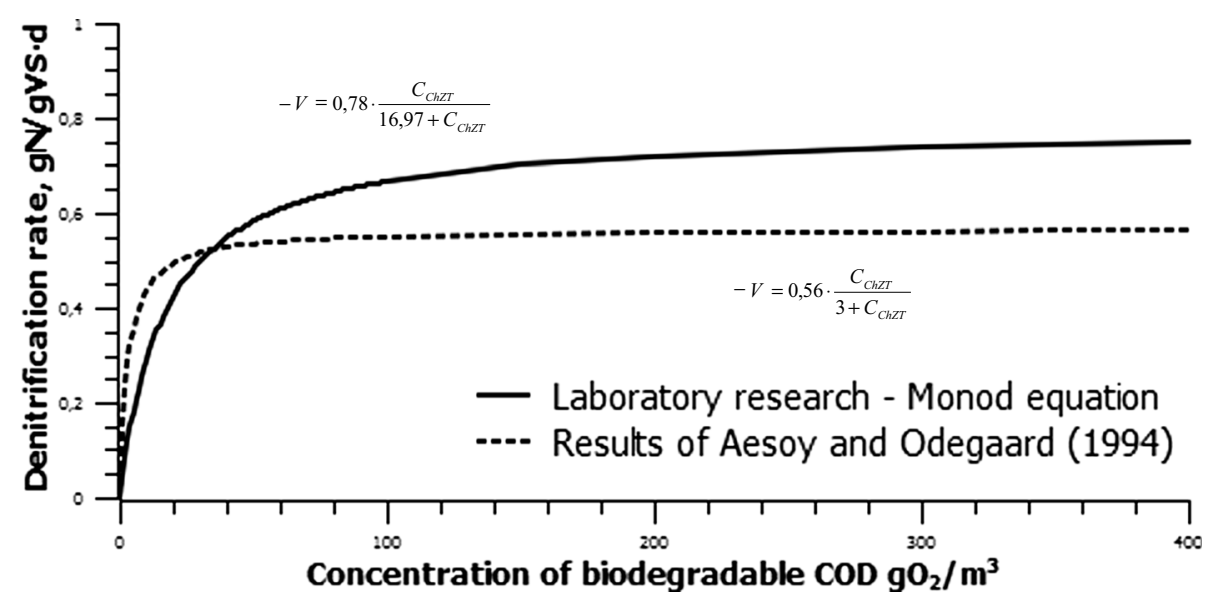

Fig. 6 Comparison of the determined Monod equation with the results of a pilot MBBR

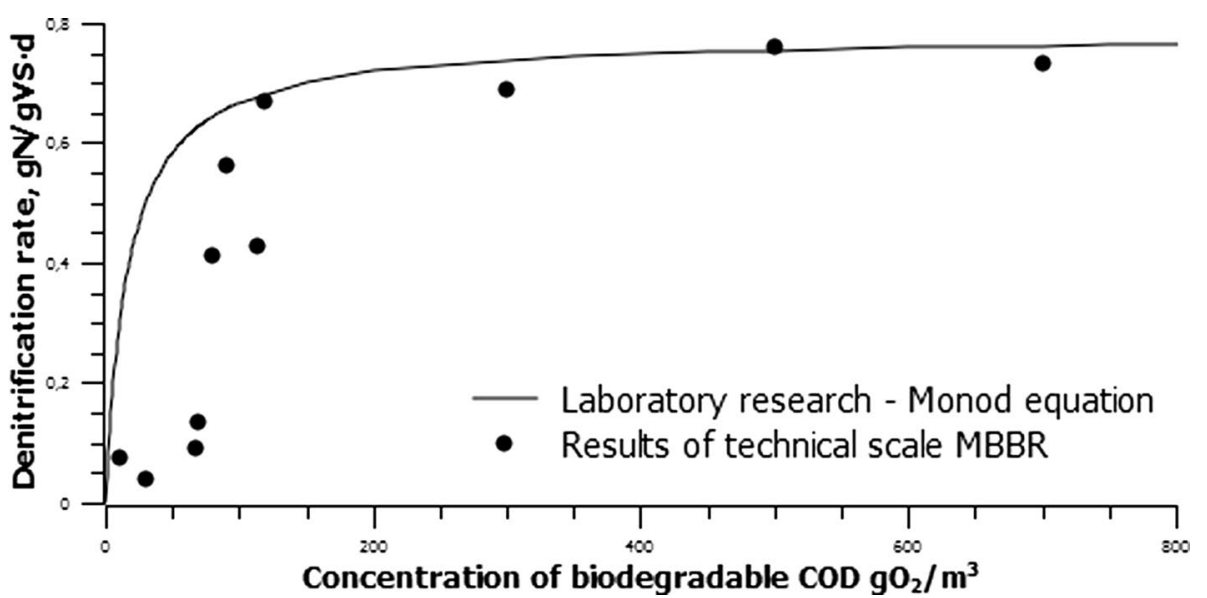


process. Furthermore, in the field research total COD was performed with samples containing a higher amount of biomass, which could affect the value of the readily biodegradable COD.

Despite small differences, a verification of Monod equation is found in laboratory proceeded satisfactorily. The values of the maximum denitrification are consistent, and the differences in the values of Monod constant are insignificant in the range of low concentrations of COD. Comparison of the results in a pilot reactor with the Monod function obtained in the laboratory is shown in Fig. 6.

The study indicates that MBBR is capable to carry out efficiently and stable denitrification. When a biomass concentration is about $2 \mathrm{~g}$ D.M./day $\mathrm{m}^{3}$ and when the COD concentration is above $120 \mathrm{~g} \mathrm{O}_{2} / \mathrm{m}^{3}$, the device is able to remove even $60 \mathrm{~g} \mathrm{NO}_{3}{ }^{-} \mathrm{N} / \mathrm{m}^{3}$ in $1 \mathrm{~h}$.

Expanding the wastewater treatment plant in Gronowo Gorne made the expected environmental effect. Previously, the object discharged wastewater about $18 \mathrm{mg} \mathrm{NH}_{4}{ }^{+}-\mathrm{N} /$ $\mathrm{dm}^{3}$ and $37 \mathrm{mg} \mathrm{NO}-\mathrm{N} / \mathrm{dm}^{3}$. After joining the MBBR to the technological system and after a period of adaptation biomass, effluent did not exceeded $6 \mathrm{mg} \mathrm{NH}_{4}{ }^{+}-\mathrm{N} / \mathrm{dm}^{3}$ and $6 \mathrm{mg}$ $\mathrm{NO}_{3}-\mathrm{N} / \mathrm{dm}^{3}$. Total nitrogen removal efficiency increased from 53.5 to $86.0 \%$.

In this study, a relatively high efficiency of total nitrogen removal was achieved. Comparing this value with other methods used to carry out denitrification, it can be concluded that the effectiveness of the process depends not only on the reactor type, but also of its location in the technological system. The process is the most efficient (at 85-95\%), when the denitrification is performed simultaneously or at the end of the system with the addition of external organic carbon source. (Odegaard 2005; Dymaczewski 2011; Qiqi et al. 2012; Lariyah et al. 2016; Kopeć et al. 2016; Chen et al. 2016).

Monod constants in the equation results indicate a higher maximum rate of denitrification $\left(V_{\max }\right)$ than in the activated sludge. However, it should be remembered that there are two types of biomass in MBBR, because besides the suspended form there is also a biomass on EvU Perl filling in the form of a biofilm. There is a phenomenon of diffusion in the biofilm, so the constant $K_{\mathrm{ChZT}}$ is higher than in the activated sludge. These differences between MBBR and AS make the Monod equation for both these methods of wastewater treatment depend on other factors and there is no point in comparing them.

The external carbon source used in the experiment was easily consumed by denitrifying microorganisms, which causes their rapid growth and denitrification occurs efficiently. It can be used in non-urbanized areas, where efficient installations with short wastewater retention times are useful. From the calculations, it is known that the reactor is able to remove $60 \mathrm{mg} \mathrm{NO}-\mathrm{N}$ in $1 \mathrm{~h}$.

\section{Conclusion}

Assessing the effect of moving bed reactor, it can be considered that the device is capable to the efficient post-denitrification with high rate and efficiency of $86.0 \%$. Good performance of reactor is confirmed by determined kinetic constants: the maximum rate of denitrification $\left(V_{\max }\right)$ of $0.73 \mathrm{~g} \mathrm{NO}_{3}{ }^{-}-\mathrm{N} / \mathrm{g}$ D.M./day and Monod constant for substrate $\left(K_{\mathrm{COD}}\right)$ amounting $16.97 \mathrm{~g} \mathrm{O}_{2} / \mathrm{m}^{3}$.

Hofstee-Eadie linearization method used to determine the constants turned out to be correct, even with a small number of data. Using this method, Monod equation for the denitrification process in the reactor was determined with a determination coefficient of 0.84 . A high correlation means that there is a strong relationship between the denitrification rate and the concentration of the organic matter dissolved in wastewater. In a pilot MBBR maximum rate of denitrification may be obtained starting at $120 \mathrm{mg} \mathrm{O} / \mathrm{dm}^{3}$, which means the Brennta Plus preparation is an efficient source of external organic carbon.

The advantage of the process is the ability to change the degree of the reactor filling, which makes this method very flexible. An additional benefit is the immobilization of a small amount of biomass on the surface of carriers, so that generally intense recirculation of wastewater is not important. A moving bed is a habitat of rapidly reproducing microorganisms, so that the MBBR is less prone to 
leaching the biomass for example due to the intense flow of wastewater.

The presence of two types of biomass (suspended and attached biomass) in one reaction space causes the rise of the denitrification rate. It can be the explanation, why recently so often the existing WWTPs are adapted to increasing loads by adding a moving bed biofilm reactors to activated sludge systems. Moreover, the potential of MBBRs can be used to remove large concentrations of contaminants for the treatment of leachate from municipal sludge dewatering or industrial wastewater.

Assessing the moving bed biofilm reactor in terms of the use in small plants in scattered settlement, it can be stated that it is an appropriate device to prevent the ingress of oxygen forms of nitrogen to surface waters, and thus contribute to improve their quality.

Moreover, the authors of paper consider it important to develop and test in practice the method for determining the kinetic constants. The presented method can be used for any other device used in sanitary engineering.

Acknowledgements Ekofinn-Pol Ltd., Poland for constructing and accessing moving bed biofilm reactor.

Open Access This article is distributed under the terms of the Creative Commons Attribution 4.0 International License (http://creativeco mmons.org/licenses/by/4.0/), which permits unrestricted use, distribution, and reproduction in any medium, provided you give appropriate credit to the original author(s) and the source, provide a link to the Creative Commons license, and indicate if changes were made.

\section{References}

Aesoy A, Odegaard H (1994) Denitrification in biofilms with biologically hydrolyzed sludge as carbon source. Water Sci Technol 29(10-11):93-100

APHA (1992) Standard methods for examination of water and wastewater, 18th edn. American Public Health Association/American Water Works Association/Water Environment Federation, Washington, DC, USA

Aspegren H, Nyberg U, Andersson B, Gotthardsson S, Jansen JC (1998) Post denitrification in a moving bed biofilm reactor process. Water Sci Technol 38(1):31-38

Cema G, Sochacki A, Kubiatowicz J, Gutwiński P, Surmacz-Górska J (2012) Start-up, modelling and simulation of the anammox process in a membrane bioreactor. Chem Process Eng 33(4):639-650

Chen H, Liu Y, Ni B, Wang Q, Wang D, Zhang C, Li X, Zeng G (2016) Full-scale evaluation of aerobic/extended-idle regime inducing biological phosphorus removal and its integration with intermittent sand filter to treat domestic sewage discharged from highway rest area. Biochem Eng J 113:114-122

Dymaczewski Z (2011) Poradnik eksploatatora oczyszczalni ściekówpraca zbiorowa (Handbook for the Operator of the Wastewater Treatment Plant—Group Work). Polskie Zrzeszenie Inżynierów i Techników, Poznań

Gajewska M, Kopeć L, Obarska-Pempkowiak H (2011) The operation of a small wastewater treatment facilities in a scattered settlement. Yearbook of The Environment Protection 13:207-225

Henze M, van Loosdrecht MCM, Ekama GA (2008) Biological wastewater treatment: principles, modeling, and design. IWA Publishing, London

Jucherski A, Nastawny M (2012) Effectiveness of removing nitrogen compounds from domestic sewage in trickling LECA beds of different hydraulic and organic substrate loads. Probl Agric Eng 78:171-181

Klimiuk E, Lossow K, Bulińska M (1995) Kinetyka reakcji i modelowanie reaktorów biochemicznych $\mathrm{w}$ procesach oczyszczania ścieków (Kinetics of reactions and biochemical reactors modeling in wastewater treatment). Art, Olsztyn, Wydawnictwo, p 158

Kopeć $Ł$, Drewnowski J, Kopeć A (2016) The application of moving bed biofilm reactor to denitrification process after trickling filters. Water Sci Technol 74(6):1-8

Lariyah MS, Mohiyaden HA, Hayder G, Hussein A, Basri H, Sabri AF, Noh MN (2016) Application of moving bed biofilm reactor (MBBR) and integrated fixed activated sludge (IFAS) for biological river water purification system: a short review. In: IOP conference on series: earth and environmental science, vol 32

Liwarska-Bizukojć E (2014) Modelowanie procesów oczyszczania ścieków metodą osadu czynnego (Modeling of wastewater treatment processes using activated sludge). Wyd. Seidel-Przywecki Sp. z o.o, Józefosław, p 251

Mąkina J (2006) Performance prediction of full-scale biological nutrient removal systems using complex activated sludge models. Veröffentlichungen des Institutes für Siedlungswasserwirtschaft und Abfalltechnik der Universität Hannover, Institut für Siedlungswasserwirtschaft und Abfalltechnik. Hannover, zeszyt 136, p 334

Metcalf \& Eddy Inc., Tchobanoglous G, Burton FL, Tsuchihashi R, Stensel HD (2013) Wastewater engineering: treatment and resource recovery, 5th edn. McGraw-Hill Education-Europe, London

Obarska-Pempkowiak H, Gajewska M, Wojciechowska E, Pempkowiak J (2015) Treatment wetlands for environmental pollution control. Springer, Cham

Odegaard H (2005) Combining CEPT and biofilm systems. In: IWA international conference on nutrient management in wastewater treatment processes and recycle streams, Krakow, pp 425-433

Onnis-Hayden A, Gu A (2008) Comparisons of organic sources for denitrification: biodegradability, denitrification rates, kinetic constants and practical implication for their application in WWTPs. In: Proceedings of the 81st annual water environment federation technical exhibition and conference, Chicago, Illinois, Oct. 18-22; Water Environment Federation: Alexandria, Virginia, pp 253-273

Pastorelli G, Andreottola G, Canziani R, Darriluat C, de Fraja Frangipane E, Rozzi A (1997) Organic carbon and nitrogen removal in moving-bed biofilm reactors. Water Sci Technol 35(6):91-99 
Qiqi Y, Qiang H, Husham TI (2012) Review on moving bed biofilm process. Pak J Nutr 11:804-811

Rusten B, Eikebrokk B, Ulgenes Y, Lygren E (2006) Design and operations of the Kaldnes moving bed biofilm reactors. Aquacult Eng 34:322-331

Sytek-Szmeichel K, Podedworna J, Augustyniak P (2016) Startup strategy for nutrient removal in moving bed sequencing batch biofilm reactor. In: 8th Eastern European IWA young water professional's conference, 12-14 May, Gdansk University of Technology, Gdansk, Poland, pp 609-617

Szewczyk KW (2005) Bilansowanie i kinetyka procesów biochemicznych (Balancing and kinetics of biochemical processes). Oficyna Wydawnicza Politechniki Warszawskiej, Warszawa, p 102

Yen-Hui L (2008) Kinetics of nitrogen and carbon removal in a movingfixed bed biofilm reactor. Appl Math Model 32(11):2360-2377 